\title{
Effects of mammae hand massages on oxytocin release, milk yield, and milk quality in dairy cows
}

\author{
Inggit Kentjonowaty *,1, Achmad Bagus Adhiluhung Mardhotillah 1, Trinil Susilawati ${ }^{2}$, \\ Puguh Surjowardojo ${ }^{2}$
}

${ }^{1}$ Faculty of Animal Science, University of Islam Malang, East Java, 65144

${ }^{2}$ Faculty of Animal Science, University of Brawijaya, East Java, 65144

*Correspondence: inggit.kentjonowaty@unisma.ac.id

Received: March 5th 2021 ; Accepted: October 25th, 2021 ; Published online: November 17th 2021

\section{Abstrak}

Tujuan: Tujuan dari penelitian ini adalah untuk mengevaluasi pengaruh Mammae Hand Massages (MHM) identik dengan 1-1,6 Volt terhadap pelepasan oksitosin, produksi susu, dan kualitas susu pada sapi perah.

Metode: Dua belas ekor sapi perah dengan kriteria sebagai berikut: umur 5 tahun, bulan laktasi ke-1 sampai ke-9, dan berat badan rata-rata $390 \pm 5,55 \mathrm{~kg}$. Metode eksperimen menggunakan Rancangan Acak Kelompok (RAK) dengan 4 perlakuan, yaitu T0 (tanpa MHM), T1 (MHM selama 20 detik), T2 (MHM selama 50 detik), dan T3 (MHM selama 80 detik) dengan variable yaitu pelepasan oksitosin, produksi susu, dan kualitas susu.

Hasil: Data yang diperoleh dianalisis menggunakan analysis of variance (ANOVA). Hasil penelitian menunjukkan bahwa MHM berpengaruh sangat nyata terhadap produksi susu $(P<0,01)$ yang dibuktikan dengan perlakuan MHM 50 detik memperoleh rata-rata produksi susu tertinggi (13.08 \pm 3.38 liter/ekor/hari) dibandingkan dengan perlakuan MHM 20 detik, MHM 80 detik dan kontrol. MHM (1-1,6 volt) selama 50 detik menghasilkan pelepasan oksitosin tertinggi (0,22955 pcg / $0,1 \mathrm{~mL}$ ) pada 240 detik dibandingkan tanpa perlakuan, MHM 20 detik dan 80 detik. Begitu pula dengan prosentase kadar protein susu $(2,96 \pm 0,03)$ dan kadar lemak susu $(4.27 \pm 0.70)$ tertinggi pada MHM 50 detik.

Kesimpulan: Dapat disimpulkan bahwa MHM (1-1,6 volt) selama 50 detik meningkatkan pelepasan oksitosin, produksi susu, dan kualitas susu ditinjau dari prosentase kadar protein dan lemak susu.

Kata Kunci: hipofisis posterior; kualitas susu; pelepasan oksitosin; produksi susu; sapi perah FH crossbreed

\section{Abstract}

Objective: The objective of this study was conducted to evaluate the effects of Mammae Hand Massages (MHM) on oxytocin release, milk yield, and milk quality in dairy cows.

Methods: Twelve dairy cows with the following criterion: 5-yr-old, 1st to 9th month of lactation, and average body weight of $390 \pm 5.55 \mathrm{~kg}$ were used. Cows were assigned in a randomized block design with 4 treatments, i.e T0 (without massage), T1 (MHM for 20 s), T2 (MHM for 50 s), and T3 (MHM for $80 \mathrm{~s}$ ). Oxytocin release, milk yield, and milk quality were measured accordingly.

Results: The data obtained were analyzed using analysis of variance (ANOVA). The results showed that MHM had a very significant effect on milk production $(\mathrm{P}<0.01)$ as evidenced by the $\mathrm{MHM}$ 
$50 \mathrm{~s}$ treatment obtained the highest average milk production (13.08 \pm 3.38 liters/head/day) compared to the MHM $20 \mathrm{~s}$, MHM $80 \mathrm{~s}$ and control. MHM (1-1.6 volts) for $50 \mathrm{~s}$ resulted in the highest release of oxytocin $(0.22955 \mathrm{pcg} / 0.1 \mathrm{~mL})$ at 240 seconds compared to control, MHM $20 \mathrm{~s}$ and $80 \mathrm{~s}$. Likewise, the percentage of milk protein content $(2.96 \pm 0.03)$ and milk fat content $(4.27 \pm 0.70)$ was highest at MHM $50 \mathrm{~s}$.

Conclusions: It can be concluded that MHM (1-1.6 volts) for 50 seconds increases the release of oxytocin, milk production, and milk quality in terms of the percentage of milk protein and fat content.

Keywords: dairy cow FH crossbreed; milk quality; milk yield; oxytocin release; posterior pituitary

\section{INTRODUCTION}

The main objectives of dairy cattle farming are to provide high-quality milk, increase milk yield and maintain udder health [1]. Automatic Milking System (AMS) method can increase in milking frequency, which should positively affect milk production [2]. However, that equipment is expensive for farmers. Some factors play a significant effect on the variations of milk quality and milk yield, including genetic and non-genetic factors. Milking management is a non-genetic factor that greatly affects milk production. It includes udder preparation (udder massage), milking methods, and teat dipping. Mammae Hand Massage (MHM) is a method of milking that is often used to stimulate milk secretion by signaling the posterior pituitary gland to produce oxytocin [3]. The milking process is allowed to be managed by an exogenous oxytocin (OT). Oxytocin injections cause increased OT blood levels which results in the prolonged myoepithelial and alveolar contractions that ultimately increase milk yield [4]. MHM is effective to stimulate milk-let-down, but there was an interval between the time at stimulation and the time at initial milking. Reimers [5] reported that massage durations $(10,30$, and $60 \mathrm{~s}$ ) had a significant effect on milk production. Meanwhile, Kentjonowaty et al., [6] found that $90 \mathrm{~s}$ was the best interval between the time at stimulation and time at milking to produce the best persistence of oxytocin. The oxytocin starts working around 1-2 $\mathrm{min}$ after stimulation [7]. Milk usually contains a somatic cell count (SCC), which is an indicator of udder health. The amount of SCC in milk depends on the level of blood oxytocin.
When doing massage to the mammae, the dairy cows should not feel pain but must feel comfortable. Therefore, it is necessary needed to measure the pressure of MHM and the comfortable effect of cows. The pressure of MHM can be measured using a PVDF sensor that is bonded on the beam specimen at one end and the ultrasonic guided waves are launched with a piezoelectric wafer bonded on another end of the beam. Sensitivity of PVDF sensor in terms of voltage is obtained for increasing number of thermal cycles. Piezoelectric-film sensor, which contains piezoelectric materials that can convert mechanical energy into electrical energy [8]. Milk yield and milk quality are also affected by the milking method. Machine milking results in a higher milk yield than hand milking. In addition, the best hand milking method is a combination of whole hands and strippen [9]. In Indonesia, the milking methods used in dairy cattle farming vary. Livestock keepers may only use machine milking, another may use a combination of the milking machine and strippen or a combination of whole hand and strippen. Eventually, it is important to determine the best duration of MHM as a pre-milking stimulation technique and the best milking method to achieve the goals of milking.

Based on the above reasons, this study was conducted to evaluate the effects of Mammae Hand Massages (MHM) on oxytocin release, milk yield, and milk quality in dairy cows.

\section{MATERIALS AND METHODS}

\section{Materials design}

Twelve dairy cows with the following criterion: 5 -yr-old, $1^{\text {st }}$ to $9^{\text {th }}$ month of lactation, 
and average body weight of $390 \pm 5.55 \mathrm{~kg}$ were used in this study. They were treated under similar maintenance management and fed similar types and amounts of diets at UPT PT \& HMT Batu, East Java. All animals investigated had good udder health. Experimental method is used by a randomized block design with 4 treatments, i.e. T0 (without massage), T1 (MHM for $20 \mathrm{~s}$ ), T2 (MHM for $50 \mathrm{~s}$ ), and T3 (MHM for $80 \mathrm{~s}$ ).

\section{Milking preparation}

Cows were fed concentrate at 04.30 am. The cages and milking equipment were cleaned. Cows were washed and their udders were smeared with vaseline. Cows were rested for $30 \mathrm{~min}$. and treated with mammary hand massage according to the treatments. The udder pressure was measured using a piezoelectric sensor. Before milking using a bucket-type milking machine, the cows were given 90 s. Milk yield and milk quality were measured.

\author{
Determination of oxytocin, milk yield, and \\ milk quality
}

Oxytocin release was determined as per the method described previously [10]. Briefly, oxytocin antibodies were dissolved in $1 \mathrm{~mL}$ PBS, diluted in a buffer coating $\mathrm{pH}$ 9.6, and incubated overnight at $40^{\circ} \mathrm{C}$. They were washed with PBS-T 3 times for $60 \mathrm{~s}$ each, blocked with $1 \%$ BSA, and left for an hour. Antibodies were washed again with PBS-T 3 times for $60 \mathrm{~s}$ each. Blood plasma (primary antibody) was coated with BSA $1 \%$ at $37^{\circ} \mathrm{C}$ for 2 hours and washed with PBS-T 3 times for 60 $\mathrm{s}$ each. Anti-rat IgG (secondary antibody) was coated with TBS $(1: 250)$, incubated at $37^{\circ} \mathrm{C}$ for an hour, and washed 3 times with PBS-T for 60 $\mathrm{s}$ each. The substrate used was PnPP (1 tablet) in $5 \mathrm{ml}$ diethanolamine ( $\mathrm{pH} 9.8$ ) and incubated at $37^{\circ} \mathrm{C}$ for $30 \mathrm{~min} .3 \mathrm{ME} \mathrm{NaOH}$ was used to stop the reaction. After 10 and $15 \mathrm{~min}$, the oxytocin levels were determined using the ELISA reader $405 \mathrm{~nm}$ OD. Milk yield was determined in the morning and evening during the experiment ( $15 \mathrm{~d}$ ) and measured as follows [9] (Hemme, 2010):

$$
\sum \text { Milk Production }=\frac{(0.383 \times \% \text { fat }+0.242 \times \% \text { Protein }+0.7832)}{3.1138}
$$

Specific gravity, milk fat, and milk protein were measured to determine milk quality using lactoscan. Briefly, $40 \mathrm{~mL}$ milk samples were put into a beaker glass and the power of lactoscan was switched on. The analysis pipe and $\mathrm{pH}$ meter probe was inserted into the sample vial. The enter button was pressed and the menu was selected according to the types of milk. The analysis results were displayed on the glass screen.
After completing the analysis, the menu button was pressed and the cleaning position was selected. The detector was washed with a daily cleaner solution. The lactoscan was switched off.

\section{Data analysis}

Oxytocin release, milk yield, and milk quality among treatments were analyzed using analysis of variance (ANOVA).

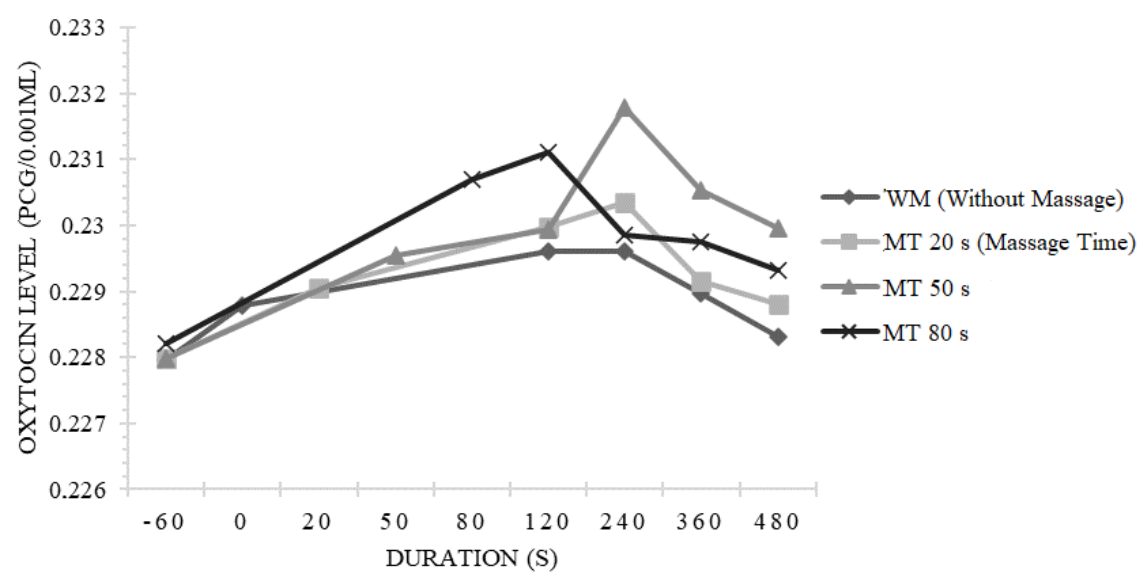

Figure 1. Effect of MHM treatments on oxytocin release 


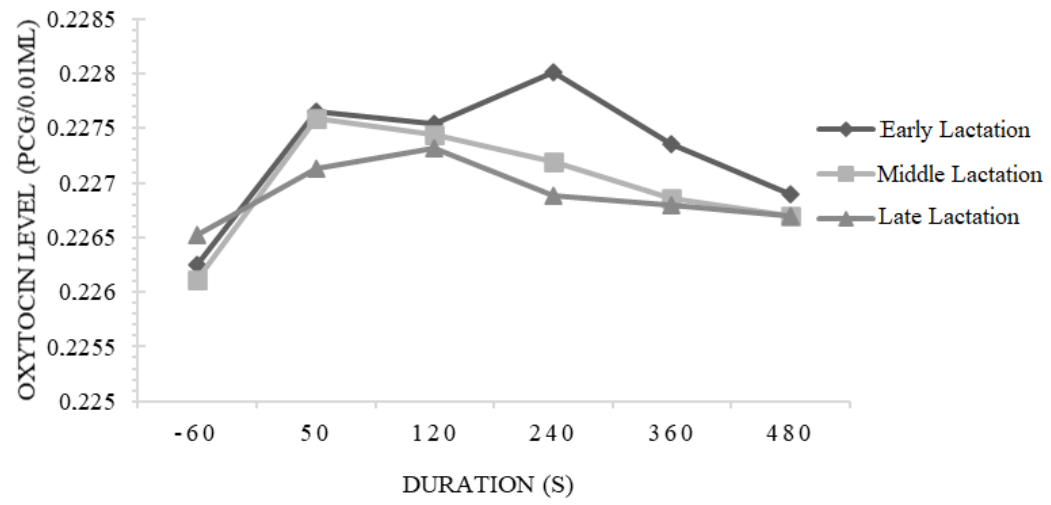

Figure 2. Oxytocin release in each lactation group

\section{RESULTS}

The effect of MHM treatments on oxytocin release of dairy cows are showed in Figure 1. Based on Figure 1, MHM 50 s group, oxytocin release increased gradually and reached its highest peak at the 4 th $(240 \mathrm{~s})$ blood collection, which steadily decreased until 480 s. Differences in oxytocin release among treatments may be attributed to the duration of the massage, which further affects oxytocin release from the posterior pituitary.

Moreover, the application of MHM in Table 1 was significantly affected milk yield $(\mathrm{P}<0.01)$. The highest milk yield was observed in MHM $50 \mathrm{~s}$ group $(13.08 \pm 3.38 \mathrm{lt} / \mathrm{head} / \mathrm{d})$ as well, followed by MHM 20 s, MHM 80 s, and control (without MHM) groups.

\section{Oxytocin release on difference lactation stages}

By doing Mammae Hand Massage (MHM) for $80 \mathrm{~s}$, the posterior pituitary could optimally secrete oxytocin (Figure 2).
However, the oxytocin level in this treatment reached its highest peak before milking. This is because $80 \mathrm{~s}$ was the longest time for the massage and there was interval time (90 s) between final massage and initial milking (Figure 1 and Figure 2).

\section{Effects of mammae hand massage (MHM) in each lactation stages on the milk yield}

The effects of Mammae Hand Massage (MHM) in each lactation group on the milk yield showed in Table 2. The results showed that the MHM and lactation stage had no significant effects $(\mathrm{P}>0.05)$ on the milk yield. It is noted that the total dry matter content in milk was relatively similar among treatments.

\section{Effect of mammae hand massage (MHM) on average milk content}

MHM had no significant effect $(\mathrm{P}>0.05)$ on milk fat (Table 4), but the effect of MHM treatments on milk fat contents tends to more high percentage on late lactation. The higher fat contents showed on the MHM for $50 \mathrm{~s}$

Table 1. Average of Daily Milk Yield in Each MHM Treatment

\begin{tabular}{lc}
\hline \multicolumn{1}{c}{ Treatment } & Milk Yield (liter/head/day) \\
\hline Without Massage (Control) & $9.84 \pm 2.94^{\mathrm{a}}$ \\
Massage Time (80 Second) & $11.01 \pm 3.60^{\mathrm{a}}$ \\
Massage Time (20 Second) & $11.65 \pm 3.40^{\mathrm{ab}}$ \\
Massage Time (50 Second) & $13.08 \pm 3.38^{\mathrm{bc}}$ \\
\hline
\end{tabular}

$a, b, c$ Superscript which is showed significant different $(\mathrm{P}<0.01)$

Table 2. Average of Daily Milk Yield in Each Lactation Group

\begin{tabular}{lc}
\hline \multicolumn{1}{c}{ Group } & Milk Yield (liter/head/day) \\
\hline Early Lactation (1-3 months) & $13.75 \pm 1.45^{\mathrm{a}}$ \\
Middle Lactation (4-6 months) & $12.83 \pm 1.52^{\mathrm{a}}$ \\
Late Lactation (7-9 month) & $7.60 \pm 1.21^{\mathrm{b}}$ \\
\hline a-b Superscript which is showed significant different $(\mathrm{P}<0.01)$ &
\end{tabular}


Table 3. Effect of lactation stages and MHM treatments on average density of milk $\left(\mathrm{gr} / \mathrm{cm}^{3}\right)$

\begin{tabular}{|c|c|c|c|c|c|}
\hline \multirow{2}{*}{ Treatment } & \multicolumn{3}{|c|}{ Group } & $\sum$ & $X$ \\
\hline & Early lactation & Middle lactation & Late lactation & & \\
\hline T0 & 1.03 & 1.03 & 1.03 & 3.08 & $1.03 \pm 0.00074$ \\
\hline $\mathrm{T} 1$ & 1.03 & 1.03 & 1.03 & 3.08 & $1.03 \pm 0.00057$ \\
\hline $\mathrm{T} 2$ & 1.03 & 1.03 & 1.03 & 3.09 & $1.03 \pm 0.00035$ \\
\hline T3 & 1.03 & 1.03 & 1.03 & 3.08 & \\
\hline$\sum$ & 4.11 & 4.11 & 4.12 & & \\
\hline Average & $1.03 \pm 0.00091$ & $1.03 \pm 0.00109$ & $1.03 \pm 0.0005$ & & \\
\hline
\end{tabular}

(5.08) in late lactation than other treatments in the same group.

Application of MHM and stages of lactation had no significant effect $(\mathrm{P}>0.05)$ on milk protein (Table 5). The interesting part showed the total milk protein content in the MHM for $50 \mathrm{~s}$ (T2) which had a higher value than other treatments. It was indicated that treatment of MHM for $50 \mathrm{~s}$ has a high percentage on each group.

\section{DISCUSSIONS}

Based on Figure 1, MHM 50 s may be able to stimulate the posterior pituitary to produce oxytocin, which in turn induces the construction of myoepithelic cells surrounding each alveolus, causing milk ejection. External stimuli can produce impulses, which are transmitted by afferent sensory nerves through the segmental Central Nervous System (CNS) to The Paraventricular Nuclei (PVN) and Supra Optic Nuclei (SON) of the hypothalamus, then transported to the posterior pituitary to promote oxytocin release and secreted from the bloodstream into the udder [11]. It stimulates the construction of myoepithelic cells surrounding alveoli, and milk was released [3]. Bruckmair and Wellnitz [7] concluded that milk ejection occurs about 40-120 s after udder stimulation. Similarly, Maciel [12] reported that oxytocin begins working about 60-120 s after stimulation. Around these times, the oxytocin reaches the udder and milk ejection is released; milk production reaches its highest peak at about 2 min after installation of the milking machine.

Table 4. Average milk fat contents (\%) in each lactation and MHM treatment

\begin{tabular}{|c|c|c|c|c|c|}
\hline \multirow{2}{*}{ Treatment } & \multicolumn{3}{|c|}{ Group } & \multirow{2}{*}{$\sum$} & \multirow{2}{*}{$X$} \\
\hline & Early lactation & Middle lactation & Late lactation & & \\
\hline T0 & 3.49 & 3.81 & 4.16 & 11.46 & $3.82 \pm 0.34$ \\
\hline $\mathrm{T} 1$ & 3.71 & 3.78 & 4.21 & 11.70 & $3.90 \pm 0.27$ \\
\hline $\mathrm{T} 2$ & 3.84 & 3.89 & 5.08 & 12.81 & $4.27 \pm 0.70$ \\
\hline $\mathrm{T} 3$ & 3.77 & 4.02 & 4.23 & 12.02 & $4.01 \pm 0.23$ \\
\hline$\sum$ & 14.81 & 15.50 & 17.68 & & \\
\hline Average & $3.70 \pm 0.15^{* *}$ & $3.88 \pm 0.11^{* *}$ & $4.42 \pm 0.44^{*}$ & & \\
\hline
\end{tabular}

\begin{tabular}{|c|c|c|c|c|c|}
\hline \multirow{2}{*}{ Treatment } & \multicolumn{3}{|c|}{ Group } & \multirow{2}{*}{$\Sigma$} & \multirow{2}{*}{$X$} \\
\hline & Early lactation & Middle lactation & Late lactation & & \\
\hline T0 & 2.68 & 2.83 & 2.89 & 8.40 & $2.80 \pm 0.11$ \\
\hline $\mathrm{T} 1$ & 2.80 & 2.92 & 2.89 & 8.61 & $2.87 \pm 0.06$ \\
\hline $\mathrm{T} 2$ & 2.93 & 2.99 & 2.94 & 8.86 & $2.96 \pm 0.03$ \\
\hline T3 & 2.87 & 2.73 & 2.89 & 8.50 & $2.83 \pm 0.09$ \\
\hline$\sum$ & 11.28 & 11.47 & 11.60 & 34.37 & \\
\hline Average & $2.82 \pm 0.11$ & $2.87 \pm 0.11$ & $2.90 \pm 0.03$ & & \\
\hline
\end{tabular}

T0 = Without Massage; T1 = MHM for $20 \mathrm{~s} ; \mathrm{T} 2=$ MHM for $50 \mathrm{~s} ; \mathrm{T} 3=$ MHM for $80 \mathrm{~s}$ 
In addition, the effect of oxytocin hormone on milk ejection occurs only during $7 \mathrm{~min}$ [5]. Similarly, Arora [13] stated that the lack of response to normal stimuli for milk ejection and addiction in animals are the main disadvantages of continuous usage of oxytocin injections. Bruckmaeir and Blum [14] concluded that milk ejection is released about 1-2 min after stimulation, and the effectiveness of oxytocin occurs about 6-8 $\mathrm{min}$.

The highest milk yield was observed in MHM $50 \mathrm{~s}$ group $(13.08 \pm 3.38 \mathrm{lt} /$ head/day $)$ rather than the control group which lower milk yield $(9.84 \pm 2.94 \mathrm{lt} / \mathrm{head} /$ day) because the posterior pituitary did not secrete oxytocin optimally. Similar to the results of this study, Williams [15] and Reimers [5] reported that udder stimulation before milking increases milk yield in dairy sheep and oxytocin release in dairy cows, respectively. Udder stimulation also affects two-minute milk yield and time in low milk flow rate in dairy cows [15]. Furthermore, udder stimulation has been reported to have a significant effect on average daily yields of actual and 7\% FCM in buffaloes [14]. However, udder stimulation for less than $10 \mathrm{~s}$ is not able to induce milk-let-down [15].

The posterior pituitary had optimally secreted oxytocin in the treatment of MHM $80 \mathrm{~s}$ (Figure 2). Besides, the levels of oxytocin at the 4th minute started to decline, which in turn decrease the rate of milk ejection. This indicated that the effectiveness of oxytocin in this MHM $80 \mathrm{~s}$ group was the lowest. Wieland et al. [16] concluded that the effectiveness of oxytocin is only $5 \mathrm{~min}$, and the milk ejection occurs at 20-60 s after udder stimulation [5]. In this period, the oxytocin reaches the udder, and milk is released optimally, starting from 60 to $90 \mathrm{~s}$ after stimulation. Milk ejection reaches the highest peak about 2 min from the time of milking machine installation. It was notable that the effect of oxytocin is only for $7 \mathrm{~min}$ [5]. Therefore, milking must be completed within $7 \mathrm{~min}$.

Following the results in (Table 1), the previous studies by Weiland et al. [16] and Sannino et al. [17], who reported that the quality of milk is influenced by feed consumption. The effect of milk production due to whether energy and protein are balanced in the diet, the urea concentration is outside the physiological range of values as well [18].

The MHM for $50 \mathrm{~s}$ has a high percentage (Table 4) because the milk fat has lower gravity than milk. The milk fat is always at the top layer of the milk. Thus, although the oxytocin release in the blood among treatments differed, milk fat contents were relatively similar among treatments [17]. The total protein content was high on T2 (Table 5) It is because milk protein may be emulsified homogeneously with milk. Although milk yield among treatments differed, milk protein content was relatively similar. Previous studies reported that milk protein did not differ among different maintenance management [16, 19]. Another study showed that stimulation of the vaginocervical area in the bovine was a more efficient stimulus for oxytocin release than was mammary stimulation during lactation [20].

\section{CONCLUSIONS}

Oxytocin release increased gradually and reached its highest peak at the 4th (240 s) blood collection because MHM $50 \mathrm{~s}$ may be able to stimulate the posterior pituitary to produce oxytocin. Dairy cows treated with Mammae Hand Massage (MHM) for $50 \mathrm{~s}$ (equal to $1-1.6$ volts), and rested $90 \mathrm{~s}$ before milking showed the best oxytocin profile, milk yield, and milk quality.

\section{CONFLICT OF INTEREST}

The authors declare no conflict of interest with any financial organization regarding the material discussed in the manuscript.

\section{ACKNOWLEDGMENTS}

We are grateful to the Research Institution and Community Service Division, University of Islam Malang for the financial support and institution partner of this work.

\section{REFERENCES}

1. Tancin, V., W. D. Kraetzl, D. Schams, M. Rupert, and R. M. Bruckmaier. 2010. 
The effects of condisioning to suckling, milking and of calf presince on the realease of oxytocin in dairy cows. Appl. Anim. Behav. Sci. 1(7):235-246. Doi: 10.1016/s0168 -1591(01)00113-7

2. Bach, A., M. Devant, C. Igleasias, and A. Ferrer. 2009. Forced traffic in automatic milking systems effectively reduces the need to get cows, but alters eating behavior and does not improve milk yield of dairy cattle. J. Dairy Sci. 92:1272-1280. Doi: 10.3168/jds.2008-1443

3. Sudono, A., R. F. Rosdiana and B. F. Setiawan. 2013. Breeding dairy cows intensively. PT Agro. Med. Pus., Bogor.

4. Faraz, A., A. Waheed, M. M. Nazir, A. Hameed, N. A. Tauqir, R. H. Mirza, H. M. Ishaq, and R. M. Bilal. 2020. Impact of oxytocin administration on milk quality, reproductive performance and residual effects in dairy animals - A Review. Punjab Univ. J. Zool. 35(1):61-67. Doi: 10.17582/ journal.pujz/2020.35.1.61.67

5. Reimers. Veterinary endocrinology and reproduction [Internet]. T. J. Reimers: 2007. [cited 2021 Feb 15]. Available from: https://www.wiley.com/en-us/McDonald $\% 27 \mathrm{~s} . h \mathrm{tml}$

6. Kentjonowaty, I., P. Trisunuwati, and Aulanni'am. 2010. Role of neuro endocrinal pathways toward on optimalization of oxytocin content in blood, against quality and quantity of milk production by influencing udder massage method on dairy cattle. Proc. Pros. Anim. Prod. in Dev. Coun. pp. 99.

7. Bruckmaeir, R. M. and O. Wellnitz. 2008. Introduction of milk ejection and milk removal in different production systems. J. Anim. Sci. 4(86):15-20. Doi: 10.2527/jas. 2007-0335

8. Vivek, T., D. Rathod, R. Mahapatra, A. Jain, A. Gayathri. 2012. Ultrasonic performance of the PVDF thin film sensors under thermal fatigue. Proc. Behav. Mech. of Multifunc. Mat. and Comp. pp. 83420E. Doi: 10.1117/12.917603

9. Kentjonowaty, I. and D. retnaningsih. 2010. The effect of using the alternative Minangka dairy cow kanggo checker method is improving the quality of lan panrima milk. J. Res. Al-Buhuts Univ. Islam. Mlg. 4(20):27-30.

10. Hemme. For a better understanding of milk production world-wide [Internet]. Hemme, T: 2010. [cited 2021 Feb 20]. Available from: http://www. Ifcdairy.org

11. Malmkvist, J., B. M. Pedersen, L. J. Jorgensen, E. Thodberg, K. Chaloupkova, R. M. Bruckmaier. 2009. Effect of Thermal Environment on Hypothalamic-PituitaryAdrenal Axis Hormons, Ocytocin and Behavioural Activity in Periparturient Sows. J. of Animal Sci. 87:2796-2805. Doi: 10.2527/jas.2008-1592

12. Maciel, J. M. 2016. Impact of some farmrelated practices and first processing steps on milk quality for cheese production. Dept. Food. Sci., Tjele.

13. Arora. No side-effect of oxytocin on animal health, milk Study [Internet]. Arora P: 2016. [cited 2021 April 27]. Available from: www.tribuneindia.com

14. Bruckmaier R. M. and J. W. Blum. 2010. Oxytocin Release and Milk Removal in Ruminants. J. Dairy Sci. 81:939-949. Doi: 10.3168/jdsS0022-0302(98)75654-1

15. Williams T. J. 2013. Effects of udder stimulation, stage of lactation and parity on milk yield in West African Dwarf (WAD) sheep. J. Veterinar. Sci. Technol. 4(4):58-64. Doi: 10.4172/2157-7579.S1.002

16. Wieland, M., J. M. Melvin, D. V. Nydam, and P. D. Virkler. 2019. A longitudinal prospective cohort study investigating the association of premilking stimulation and teat-end shape on milking characteristics and teat tissue condition in dairy cows. J. Dairy. Res. 70(1):349-354. Doi: 10.1017/ S0022029903006216

17. Sannino, M., S. Faugno, M. Crimaldi, A. Di Francia, L. Ardito, F. Serrapica, and F. Masucci. 2018. Effects of an automatic milking system on milk yield and quality of Mediterranean buffaloes. J. Dairy Sci. 101:1-5. Doi: 10.3168/jds.201714157

18. Abde, R. E. M., S. I. A. Abou, H. M. A. Gaafar, E. M. A. A. Abdul, and H. R. Rashed. 2011. Effect of udder massage of primiparous and multiparous buffaloes on 
milk yield and composition. LRRD. 23(10):20-23.

19. Jeffrey K. and Reneau. 2009. Measures of farm management and milk quality. Proc. Nat. Masti. Counc. Annu. Meet. pp. 115119.
20.Ljoljić, D. B., I. V. Špehar, Z. Prpić, I. Vnučec, D. Samaržija. 2020. Urea concentration in goat milk: importance of determination and factors of variability. J. Cen. Euro. Agri. 21(4):707-721. Doi: 10.5513/JCEA01/21.4.3058 